\title{
The dissemination of magical knowledge in Enlightenment Germany
}

\section{The supernatural and the development of print culture}

\author{
Sabine Doering-Manteuffel
}

The so-called Age of Enlightenment has traditionally been portrayed as a phase of European history during which new philosophies came into existence concerning people's ability to determine their own fate through reason. This era saw the development of future-oriented conceptions of state and society as well as new ideas about mankind's ability to control and govern nature. The dominance of theological world-views ceded considerable ground to secular intellectual concepts. Latin disappeared as the language of elite discourse. Increased educational provision provided access to sources of knowledge that were previously unattainable to all but a few. A market for books and newspapers, for journals and weeklies developed rapidly. ${ }^{1}$ More and more people lower down the social scale became increasingly involved in a literary culture. Accordingly, the 'common' people began to learn from their history. They were taught new methods of agriculture, trade and morals, were informed of the latest achievements and news from all over the world by self-appointed public enlighteners. ${ }^{2}$ As the eighteenth century progressed the populace became increasingly divorced from the old traditional oral cultures and conceptions of the world.

Although there are some truths in this classic version of the Enlightenment there is reason to give it only partial credence, as the study of supernatural literature of the period demonstrates. The development of printed media during the second half of the seventeenth century created a new information culture, which came to play a dominant role in the spread of new, more 'rational' ideas, yet not all of the information disseminated immediately strikes one as being 'enlightened'. ${ }^{3}$ Business-minded publishers took advantage of the continued, widespread belief in magic and supernatural phenomena. Belief in miracles, magic knowledge and fortune-telling were exploited in the new market, and the more literature that was printed in general, the more magic and occult literature was also printed. By the end of the eighteenth century, the market for mass-produced literature on magic and the occult had been established, and in the following century this 
literature attracted popular attention and notoriety in a number of European countries. $^{4}$

One can see this period as giving birth to a new culture of popular magic. It was not an oral culture but a literary culture that fostered it; not the simple peasant but the publisher, the printer and the reader who cradled it; not the rural but the urban population which initially absorbed it. ${ }^{5}$ This literary occultism was a thoroughly modern phenomenon. ${ }^{6}$ At the same time it was a repackaging of centuries-old ideas and rituals. The magical literature of the Enlightenment contained instructions for the invocation of demons, recipes for conjuring love and protection against harmful spells, all to be conducted in the cottage rather than the study or laboratory. ${ }^{7}$ It included huge numbers of works on simple divination involving, for example, magic mirrors and amateur astrology. ${ }^{8}$ Furthermore, the reporting of miraculous signs, which were so popular in the sixteenth and seventeenth century, continued to play a central role in the transmission of supernaturalism. Yet it is important to be aware of distinctions between the forms of magical beliefs mentioned above and related spiritual beliefs expressive of people's devoutness. I am more concerned with a Weltanschauung (philosophy of life), which was not explicitly religious but which was nevertheless concerned with the spiritual, and derived primarily from written sources and not from the spoken word.

\section{Broadsides, pamphlets and newspapers}

Broadsides and pamphlets were early print formats, which were already penetrating the incipient media market by the mid-sixteenth century. In early modern Germany the main centres of printing were Leipzig, Frankfurt, Strasburg, Augsburg, Erfurt and Nremberg. Produced in towns and cities, they were bought in bulk for local markets and sold to the rural population by travelling hawkers. A similar distribution network of print-pedlars selling broadsides and pamphlets still existed in the nineteenth century. Undoubtedly the most popular format were the one-page broadsides, which nearly always contained illustrations, and were not only used as a source of news but also as wall decorations. They have also been found glued inside the lids of trunks, boxes and cases.

The majority of sixteenth-century broadsides and pamphlets were the products of religious propaganda. Martin Luther, one of the first media stars of print culture, demonstrated the power of simple literary forms, and deliberately exploited popular formats and idioms to spread his message of religious reformation. By the second half of the seventeenth century a more secular, sensational press can be distinguished. The content was, as in the past, still religious in nature, but the various elements were combined according to the principle of unit construction. It is during this period that we find early signs of the standardisation that characterised media in the 
modern period. This was made possible by new printing technology. The units of many broadsides consisted of a text and a picture. The text reported a miraculous occurrence, for example, and the picture provided a graphic description for the illiterate. If it concerned a celestial sign, such as a celestial army, a flying snake or some other indicative sign, then it filled the upper part of the picture. If, however, it concerned a miracle spring, corn falls or a resurrection, then a montage was created and the occurrence was superimposed into the picture of some location. These three elements - the text and the two halves of the picture - were combined at will. It thereby becomes possible to ink the sensation into a local context without having to prepare a new relief plate. By the middle of sixteenth century, this technique was already being used in the printing of religious pamphlets. In 1572, for instance, the printer Nikolaus Basse from Frankfurt printed a copy of a broadside about a food miracle in the Swabian village of Weidenstetten, which the printer Peter Hug from Strasburg also produced in the same year. ${ }^{9}$ The text is nearly identical, only the pictures are different. The picture used by Hug can be found again beneath another text produced by another printer. ${ }^{10}$ The invention of unit construction thus allowed the possibility of employing pictures and texts independently of one another. Naturally, this raises the question of the purpose of such printed material.

During Luther's time, the concept behind the portrayal of such miraculous occurrences was to induce a fear of God amongst the people. It was claimed that if there were an increase in earthly sins then a wrathful, avenging God would manifest himself. He threatened the world with war, famine and plagues. Should mankind continue to commit sin then the signs would increase accordingly. The appearance of wars, famine and plagues were to be understood as just punishment for mankind's wrongdoings. Many of the authors of pamphlets containing these kinds of messages were Lutheran preachers. ${ }^{11}$ They preached about God's signs of wrath not only from the pulpit, but also via the text-picture medium sold at markets throughout the Protestant states. The technique was taken up by publishers in Frankfurt, Strasburg, Leipzig and Augsburg. ${ }^{12}$ As these Lutheran theories about miracle signs began to dissipate towards the end of the seventeenth century, and the educated belief in miracles diminished due to new scientific and philosophical developments, the reports of miracle signs began to lose their religious content but still retained their sensational value. The stories of faces in the sky, celestial armies and the apparitions of angels continued to be disseminated widely. The hundreds of broadside and pamphlet reports of miraculous signs published during the late sixteenth and seventeenth centuries not only left their mark on generations of believers, but they also inspired a popular literature which, during the eighteenth century stripped away more and more of their theological significance. Miracle showers of flour and grain were still being quite regularly reported during the first half of the eighteenth century. 
Miraculous cornstalks with seventy-two ears, which had been reported near Strasburg back in the sixteenth century, continued to turn up two hundred years later. ${ }^{13}$ What about the story of the old derelict church in Bohemia? A church that radiated light at night, where singing was heard and where frightening faces had been seen. The story was first published in a broadside printed in Augsburg in 1614.14 During the late seventeenth and early eighteenth centuries it was printed again in tracts and erudite discourses by Erasmus Francisci. Francisci passed on these kinds of stories to his readers with the intention of proving the existence of ghosts. ${ }^{15}$ In another publication, he actually referred directly to a miracle sign report by Job Fincel, of Erfurt, believing it to be a reliable source of information about an omen of war, namely an invisible army seen in a field in Sachsen in 1553. ${ }^{16}$ Fincel was an ardent Lutheran preacher and one of the most reputable creators of such miracle reports. ${ }^{17}$ With Francisci, however, the story became less a piece of Protestant propaganda, and more a justification for the existence of demons and ghosts. He no longer believed that the omen really was a prophecy of war but he was convinced that the apparitions were genuine.

During the eighteenth century, news of such occurrences was increasingly announced in the newspapers. In 1748, for example, the Augsburger Intelligenz-Zettel reported on the 'Apparition of a Miraculous Fish' and on the finding of a 'miraculous root'. ${ }^{18}$ There had been an explosive development in the newspaper market. The first German language newspaper had already been printed in the early seventeenth century, but the periodical press really took off commercially during the eighteenth century. ${ }^{19}$ In Augsburg, for example, which had long been an influential media and printing centre, the handful of newspapers produced during the early eighteenth century swelled to around 200 by the end of the century. ${ }^{20}$ Some of them, such as the Intelligenzblätter, contained a rubric with mixed messages. And here we come across the sign reports again. By this time they were reduced to mere textual announcements. The simple illustrations, which were one of the main selling points of the broadside and chapbook, were not replicated in the newspaper format.

\section{Books and brochures}

It was not for nothing that the eighteenth century was given the derisive nickname Tintenklecksendes Säkulum (ink-spilling century). From university scholar to schoolteacher, the learned believed that they should put their thoughts down on paper. One continuing area of debate concerned the importance of the Devil. Philosophical disputes about the power of the Devil appeared in numerous publications. ${ }^{21}$ Could he metamorphose the bodies of humans? Could he make gold from base metals? Could he awaken the dead? The answers were increasingly negative. The Devil merely deluded the people with illusions in order to lead them into temptation. Furthermore, 
the concept of the Devil became more abstract, and he was no longer commonly perceived, even in popular literature, as being a physical entity walking amongst the living.

Newspapers were the preferred medium for airing one's views on a huge range of often obscure subjects. Between 1791 and 1793, for instance, the Dresdner Gelehrte Anzeiger newspaper printed articles discussing variously how to make an alcoholic spirit out of carrots, the importance of hour-glasses for pulpits in Protestant churches, and how the internal make-up of a pine-tree caterpillar was structured. A wealth of discourses materialised which may seem faintly ridiculous today, but which symbolised the Enlightenment sense of intellectual exploration, and the overwhelming urge to explain rather than just accept. ${ }^{22}$

This is well illustrated by the published exchanges between a spice trader named Tobias Conrad Hoppe from Gera, and Johann Friedrich Schreiber, a priest from the Lausitz, during the mid-eighteenth century. They argued publicly over three main issues. The first concerned whether or not the flowers found on the oak trees in the Lausitz region in the summer of 1747 were genuine roses. The second question was about the existence of unicorns, and the third considered whether or not young frogs fell out of rain clouds, as reports had suggested. These were certainly not the most pressing questions of the day, but they were unmistakably influenced by the miracle sign literature disseminated during previous decades. In 1748 both gentlemen had their correspondence printed by publishers in Leipzig and Gera. As time went by, these letters assumed the character of a polemic. Neither of the men wanted to admit that the other was right. The spice trader was an enlightened man. He vigorously held the opinion that the flowers on the oak tree were not roses but worm nests. He made it clear that unicorns did not exist, and that frogs could not fly and therefore could not fall out of the sky. The priest on the other hand had his doubts. Did nothing count anymore? Were all the miracles of nature, which God in his incomprehensible will had created, of no worth at all? Were there to be no more omens signalling precious time, hunger and war? Two seemingly irreconcilable positions faced one another.

The priest personified men of the past, the spice trader was a representative of the Enlightenment. It is remarkable that this argument of such remote questions was even printed. With it, both publicity and standardisation came into being. That is how we know today what the contemporaries concerned themselves with. It is also remarkable, however, that the dispute ended without any real conclusion. The priest gave to understand that many people still believed in these signs and that he hoped the new perspective, which attempted to put all miracles down to natural causes, would not gain acceptance. He was altogether scared. He was scared of the consequences of a dissected world. Today we sometimes, somewhat misleadingly, call this a deprivation of the world's mystique. The spiritual 
man feared that request for all creation would be lost when one no longer recognised celestial signs. He saw the approach of a vacuum. ${ }^{23}$

This clash of ideas shows that both views of the world - one founded on religion, the other on science - existed side by side. The one then separated itself off from the other and the dominance of science progressed. Public enlighteners and scientists worked with increasing energy on secular explanation and produced countless discourses on the structure of the world. Learned societies came into existence. New universities were founded and new university subjects were established. This story is sufficiently familiar, and so far we have regarded it as a success story. However, the market for publications on the supernatural continued to blossom, and assumed an increasingly occult character. They lost their religious character, but appealed to people who did not want to be totally separated from the idea that there was actually a higher, non-classifiable principle influencing fate.

At the beginning of the eighteenth century a new genre of non-fiction emerged, which was influenced by the types of issues debated by the country priest and his protagonist, and in the burgeoning newspapers. They are reminiscent of hausvater (housefather) literature and 'house books', which had circulated in both handwritten and printed form since the late Middle Ages. This literature did not merely contain practical instructions on how to care for house and garden, man and animal and so on, they also included instruction on magic and the occult. ${ }^{24}$ More so than their predecessors, they also contained ghost stories and discourses about mermaids, unicorn and werewolves. They often contained the word 'collection' in the title, and were compiled from a range of older sources, though it is difficult to pinpoint exactly from where individual passages originate. Some of it may have been fictitious. But one look is enough to realise that they dealt with a mix of old and new learned notions reworked into an accessible form.

The history of the Endter's influential Nuremberg publishing company during the late seventeenth and eighteenth centuries demonstrates well how the publishing agenda changed with regards to the printing of occult books. In the 1670 s the young Wolfgang Moritz Endter took over the large and influential family publishing house, and under his guidance business continued to flourish. It is difficult to estimate just how many works were printed at Endter's in the years between 1650 and 1800. Today there are about 2000 different titles housed in Bavarian archives. After the Thirty Years' War, Endter's printed works on everything that the literate educated classes regarded as important: mathematical textbooks, maps, city views, song books, municipal authority decrees, works on bookkeeping and banking, and, above all, editions of the Bible. ${ }^{25}$ Funeral sermons were one of the most lucrative products, which enabled Endter's to tick over financially. At least threequarters of their entire production was printed in German. Theology and specialised medical literature were the only subjects still produced in Latin. 
Yet one of the main reasons for Endter's continuing success from the late seventeenth century onwards was the shifting emphasis of production to prognostic works. Alongside learned astronomical textbooks, literature on astrology and miracle signs became an increasingly dominant commercial area at a time when astrology was under attack from Enlightenment critics. Such literature was no longer produced in the pamphlet form typical in the years before the Thirty Years' War, but as tracts and discourses, which had become the fashionable conduit for academic discussions on subjects concerning natural history. As early as 1648 a considerable number of different astrological war calendars appeared on the publisher's lists. ${ }^{26}$ Of course, this kind of prognostic calendar was hardly new. Examples can be found concerning the large comet that appeared over Europe in 1618. In 1688 and 1785 the same edition of a calendar of this kind, filled with omens and miracle signs by an author named Philemon Adelsheim was printed by Endter. Unfortunately, the number of copies made of either edition is still not known, but sales of similar literature appeared to have boomed. One reason for this is that they were adapted more and more for the lower end of the market. Towards the end of the eighteenth century they were increasingly being published under the description Bauernkalender (Peasant Calendar), which is not how they were originally titled, and denotes their reduced readership in social terms. The publisher acquired a second pillar of success with their popular editions of the Faust legend. The first Endter edition of the life of the high magician Johann Faust was published in 1647, then again in 1674, 1681 and $1717 .{ }^{27}$ At the moment it is not known whether there were later editions, but by 1717 the Faust chapbook had been bundled with two other discourses on magic and the art of invocation. ${ }^{28}$ Furthermore, from the $1720 \mathrm{~s}$ onwards Endter produced a new series of popular fortune-telling publications, in particular the Weissagungen der Sibyllen. ${ }^{29}$ Thanks to publishers like Endter, by the end of the eighteenth century literature on fortune-telling and the reading of planets had become more widely available than ever before. ${ }^{30}$ Around 1780 it was observed that in many German cities, professional fortune-tellers were making good use of such publications, much to the chagrin of some. ${ }^{31}$ Efforts made by public enlighteners to encourage people away from such publications were in vain, despite censorship laws. Their popularity remained strong well into the twentieth century. Just before the First World War, for example, a priest sneeringly remarked that every housemaid kept a planet book hidden under her pillow. ${ }^{32}$

Before moving on to Stephan Bachter's survey of grimoires it is briefly worth considering the influence this burgeoning German magic media market had in America. This has a direct connection with the question concerning the relationship between print and orality in the transmission of folk magic. In the collections of various American folklore societies, we find traces of the oral traditions of German immigrant communities. ${ }^{33}$ From these it is clear 
that the charm books first printed in Germany during the late eighteenth and nineteenth centuries were still known to the older population of Ohio, though there is little evidence of any preserved copies having survived into the second half of the twentieth century. Research on this subject has only just begun however. Folklorists have, until recently, shown more interest in the oral traditions themselves rather than their possible printed origins. ${ }^{34}$ One exception is the work of Yvonne Millspaw, who studied an ethnic German family in Pennsylvania whose members for numerous generations had been practising Braucherei (traditional magic). ${ }^{35}$ The family had arrived in America from the upper Rhine region in about 1750 . All members of the family were active in either the fundamentalist or conservative Protestant communities. At the time of the generation born around 1890, manuscripts and a book were being used in their Braucherei. The book was Johann Georg Hohmann's Long Lost Friend, a popular American charm book of the nineteenth century. Handwritten magic recipes had also been entered into the family cookbook where Millspaw found them tucked between recipes for marmalade and sand-cake. None of the orally transmitted instructions on conjuring differed in any way from the written magical instructions. So even this family were a part of the Magic Media Market, despite the fact that, at first glance, they could boast a long family tradition of orality. There was no real 'old' knowledge to be found here, which would at least have given us some indication of the magic art of the upper Rhine during the early eighteenth century - the time of the family's emigration.

\section{Grimoires and the transmission of magical knowledge}

\section{Stephan Bachter}

In the eighteenth century becoming rich and happy through magic had its difficulties, and not just from a legal point of view. ${ }^{36}$ It was not easy getting hold of the kind of literature that enabled one to conjure up wealth, good health and love. This problem of access is well illustrated by the following case from Bavaria. Around 1770, an itinerant glass-painter named Joseph Reuther was engaged in a lengthy search for literature on magic. He roamed around the small towns and villages in the provincial area between Ulm, Augsburg and Donauwörth, and while on his commercial travels asked people if they possessed any literature that helped counter life's miseries, since he wanted to make copies of them. His quest proved successful with a number of officials, soldiers and craftsmen. Reuther was not working on his own initiative, however. People actually hired him to seek out copies of magic manuscripts. He was the mediator and gatherer of magic literature, but he 
had one handicap: he had no knowledge of Latin, the language in which many books of magic were written at the time. As a result he struck up a partnership with a weaver, Christopher Reger, of Lauingen, who made copies of the texts Reuther found. Reger had been a novice with the Augustinian monks and had been through their Latin school. He was, however, a little out of practice, and had to admit that he was not able to read and understand everything in the originals, and therefore simply omitted those parts in the copies he made. When Reuther's illegal magic trade was discovered by the authorities, Reger was also hauled before the courts as an accomplice. It came to light that he was far more deeply embroiled in the world of magic literature than could be guessed at from his role as copyist. Reger strongly believed in the contents of the literature and practised the spells and conjurations elucidated in the texts. With one piece of literature in particular, the Christopherus-Gebet (Christopherus Prayer), he confessed to attempting to call up and compel a demon to hand over a hidden treasure.

Reger was not the only one in the little town of Lauingen who believed in and attempted such conjurations. During the criminal investigation a nest of treasure hunters came to light. Weavers and painters, castle guards, tailors and landladies were all involved. The handwritten instructions for performing conjurations circulated amongst them. A tailor bequeathed one such manuscript to his landlady who, in turn, passed it on to Reger's wife so that her husband, with his knowledge of Latin, could try it out and in this way make their fortune. Reger and his partners in crime prayed and conjured for many hours over a period of thirty-three nights until they were practically crooked and hunchbacked. Nevertheless they remained the poor beggars they were, and were fortunate to receive only a mild punishment by the court. ${ }^{37}$

The object of the following discussion is to examine the nature and dissemination of these Zauberbücher (books of spells) or grimoires, which contained instructions not only on how to invoke demons to find hidden treasure, but also to restore health, to reverse the effects of witchcraft and love spells and to safeguard and increase material wealth. Tracing the origins of these texts, both in their manuscript and printed form, is not easy. The place of publication and dates were often false, and equally fictional was their authorship, with some of them purporting to be the work of famous figures from the past such as Moses, Solomon, Albertus Magnus and Dr Faust. This discussion will examine the history of grimoires from the middle of the seventeenth century, since from this time there is surviving evidence of multiple copies of both handwritten and printed charm books. After 1800, not only is there a noticeable increase in the number of books in print but also in the number of handwritten copies of spell books intended for domestic use. Since 1900 there has been an immense variety of titles in mass circulation which continue to be popular today.

It is paradoxical that only since the Enlightenment have spell books been 
disseminated and taken up by wider sections of the population. Magic literature experienced a popularisation in both rural and urban society in a world in which all mystique had supposedly been dispelled. As the century of the Enlightenment came to an end a 'Magic Media Market' was being formed. ${ }^{38}$ Magic was being offered openly as, for example, in an advertisement published in the urban readership Allgemeiner Litterarischer Anzeiger, 28 March 1797, which offered for sale alchemical and magic manuscripts from the collection of a 'famous adept'. This advertisement, incidentally, provides the earliest printed reference found so far to the notorious Sixth and Seventh Books of Moses. ${ }^{39}$ In fact, it would seem that despite their supposedly venerable origins, a number of grimoire titles like the Sixth and Seventh Books of Moses, were the product of the second half of the eighteenth century.

Who were the customers who generated this burgeoning trade? The Reuther case indicates a market amongst the artisan and tradesman class, but there was also interest from those higher up the social scale. One collector of grimoire manuscripts was none other than Johann Wolfgang von Goethe. There is no evidence that Goethe had a practical interest in the occult but rather collected them out of a spirit of antiquarian interest. The author of the celebrated Faust described a certain variant of a notorious grimoire called 'Faust's Höllenzwang' ('Faust's Hell's command'), which contained a recipe to call up the demon Mephistopheles, as an 'extremely odd work of reasonable nonsense'. ${ }^{40}$ Goethe's most prized text was a manuscript entitled, 'Bibliae Magicae / das ist / Die gantze heilige Schrifft / Alten Testament / von Hanns Weymar des VI = VII Buch Mosis'. It emerges from his letters that he had been on the trail of this magic manuscript for some time and had paid such a high price for it in 1817 that he expressed some embarrassment about it. ${ }^{41}$ It consists of twenty-two loose, bronze-coated cardboard pages measuring $30.5 \times 44.5$ centimetres. They each have writing on the front and the back, mostly in blood red characters that are or at least appear to be oriental. The sections of text that are formulated in German, the headings in particular, are also written using Latin letters, which are blended with the oriental signs. Statements made by Goethe about the previous owners and age of the book, as well as examinations currently being carried out, suggest that the manuscript dates to around 1750. This means, that the 'Bibliae Magicae' of Weimar is one of the oldest manuscripts with the title 'Sixth and Seventh Books of Moses'.

Another less well-known contemporary collector, a councillor of Darmstadt called Karl Wunderlich (1769-1841), put together a large collection of grimoires during his lifetime, which today gives us an interesting insight into which titles were in circulation and available around the time that the advert in the Allgemeiner Litterarischer Anzeiger appeared. Wunderlich had studied cameral sciences in Giessen and Heidelberg and was employed as a secretary at the Herzogliche Rentkammer (Ducal tax authority). Although familiar with 
the new intellectual ideas of the 'Enlightenment' through his studies and occupation, Wunderlich retained a lifelong practical interest in the occult arts. Darmstadt was an appropriate place for a man with such interests, as the counts of Hessen-Darmstadt had a legendary reputation for calling up demons and making gold by magical means. Wunderlich's study was filled with nearly 1700 volumes, including many works on magic and alchemy, as well as all of the instruments necessary for making gold, calling up demons and hunting treasures: crucibles, ovens, test tubes, divining rods, magical circles and an Erdspiegel (instrument for looking into the future). ${ }^{42}$ Wunderlich copied several dozen magic manuscripts. Amongst them, were several texts based on the Sixth and Seventh Books of Moses, such as 'Biblia Arcana Magica Alexander nach der Traduction des VI und VII Buch Moyses nebst magischen Gesetzen', 'Rezabla wegesches harez arzas oder Geheimniße VI. Buch Mosis', and 'Rezabla wegesches harez arzas. Rabole oder Geheimniße des VI. Buchs Mosis. 1540' ('Rezabla wegesches harez arzas or Secrets of the Sixth an Seventh Books of Moses'). His collection also included several 'Höllenzwänge' manuscripts (a grimoire often used by magical treasure hunters), including one apparently formerly owned by a Jesuit, 'Hoellenzwang des Rev. Pater Eberhard Soc. Iesu Ingolstadt 1705’. There were several manuscripts attributed to Dr Faust: 'Des Doctor Faustens Rechter Geisterzwang durch welche man alle Geister citiren kann, daß sie einen in allen willfährig sein müssen. Gedruckt Anno 1511' ('Dr Faust's right command for demons'), and 'Beschwörung und Ruf des MeerGeistes Doctoris Fausti, oder des Wassergeistes Quirumndai' ('Calling up a Demon of the Sea'), 'Der schwarze Rabe. Passau, Anno 1519' ('The black raven'), as well as some more generic titles like 'Wahrhafte Beschwörung eines Schatzgeistes, daß derselbe seinen Schaz in das Zimmer bringen muß' ('True conjuration of a demon guarding hidden treasures'), 'Großer Zwang für die widerspenstigen Geister' ('Greater command for the wilful demon'), 'Schneller Ruf des Höllischen Geistes und Teufels Fürsten Aciel Nebst denen dazu benöthigten Gebeten Hinterließ P. Huber S. J. Ingolstadt 1732' ('Quick call of the demon Aciel'). One small grimoire in the collection, dedicated to calling up demons and assuring their help in the search for hidden treasures, is apparently unique to the Wunderlich collection. The writing bears the title 'Der Zwicker' ('The Pincher'), and a verse in German on the front page explains its use:

I'm called The Zwickerlein

Not known to everybody

The one to possess me will manage

to get all the treasures from the Devil.

So may look who understands:

poverty will pass. ${ }^{43}$

It is no surprise that Wunderlich also possessed a copy of the very title 
that the treasure hunters Reger and Reuther were interested in - the 'Christopherus Prayer'.

It would seem, then, that towards the end of the eighteenth century magical manuscripts were in circulation up and down the social scale, and were put together and compiled by numerous collectors. During the following century increasing numbers of spell books also found their way into print. In this respect the editions published by the Stuttgart publisher and antiquarian Johann Scheible are particularly worth noting. It was Scheible who, in 1849, published the first printed copies of the Sixth and Seventh Books of Moses. ${ }^{44}$ Although increasing numbers of grimoires were put into print, handwritten copies still continued to be produced and circulated.

There are two basic versions of the Sixth and Seventh Books of Moses, each having significantly different content, each pandering to a different market. Goethe's 'Bibliae Magicae' is representative of the 'high brow' version, which professes to contain incantations and magic signs supposedly used by Old Testament figures to perform wonders, in particular Moses' incantations over the staff, the seven plagues and the columns of smoke and fire, as described in Exodus 7-8. It is this variant in manuscript form which dates back to the mid-eighteenth century. Of a slightly later date, and more familiar to people today is the more 'low brow' variant for use in daily life, which contains recipes of sympathetic medicine and instructions on how to counteract harmful spells. In Germany both variants were printed and in circulation from the second half of the nineteenth century onwards, though it is the low brow' printed version which disseminated more widely, and found its way to America, particularly to Pennsylvania, via German emigrants. ${ }^{45}$ Even within both variants the contents of different editions varies widely, and from a detailed analysis of the borrowings, crossovers and complexities of such manuscripts and printed pamphlets, originals and copies, titles and editions, I would like to suggest a new method of examining the spell book genre, their contents and their usage in everyday practice.

Grimoires can be described as being created according to a unit construction system, as indicated by Sabine Doering-Manteuffel. Texts, pictures, names, illustrations, magic signs, titles, incantations, recipes, possible uses, dates, places of printing, publishers, legends about origins: different combinations of all these elements or units were put together by the producers of spell books, both professional publishers and those who made copies for their personal use. One result of this process is that the individual elements can lose their sense and meaning. This is illustrated by the following example of the way in which pictures and authoritative names were treated. In a rare published version of a 'Faust's Höllenzwänge' printed around 1775, though dated 'Rome 1510', and entitled D. Faust's original geister commando der Höllen und aller ander geister zwang sowohl die bösen, als guten spiritus, we find a small picture. According to the inscription that circumscribes the head of the figure, 
it depicts one Dr Habermann, otherwise described as 'Magus Habermannus', a well-educated man and powerful magician. ${ }^{46}$ However, in another Höllenzwang edition, we find a near identical picture, which this time was supposed to depict Sadock, King Solomon's high priest. So far, as an element of the unit construction system, the illustration has been combined with different names. The names Habermann and Sadock are further unit construction elements that reappear in other places in new combinations. A number of spell books were named after Dr Habermann, for example Der Goldene Habermann, which we are familiar with from manuscript copies made in Darmstadt around 1800, as well as those from the Scheible printing press from around 1850. According to the Höllenzwang in the British Library Habermann is said to have taken the grimoire out of the Vatican dungeons and had it printed. Rumours had long circulated that several powerful grimoires were kept hidden in Rome by the Catholic Church, and the phrase, 'bring a spell book from the dungeons of the Vatican', became another element in the spell book unit construction system. Habermann is sometimes claimed to have had an accomplice, a certain Hans Weymar. The name Hans Weymar is, however, just another set piece. He is also mentioned on the title page of the Höllenzwänge manuscript acquired by Goethe. These examples demonstrate well the constant to-ings and fro-ings of names, claims, illustrations and signs. ${ }^{47}$

When we hear that in the eighteenth century a certain Johann Ernst Philippi, former professor for theology in Halle, had for years earned a living by making copies of magic literature, and that when he could not get hold of the original simply reproduced the same thing himself, ${ }^{48}$ and when we remember how the compiler from Lauingen only copied whatever he could understand with his basic knowledge of Latin, then we must also suspect the purity of the transcription of this literature. New additions and adaptations were patently made to standard titles, and in this respect one wonders about which magic manuscripts and text fragments were washed up into the 'Magic Media Market' as a result of the monastic dissolutions following the secularisation moves in 1802 and 1803.

Every printed copy put on to the market could serve as a model for a handwritten copy. Likewise, every handwritten copy could be the model for a printed copy. In this way books of spells transported certain elements of magic and pansophic knowledge from the early modern period to the present. Speculations about the connection between macrocosm and microcosm, about the secrets of the cabbala or the order of hell, which were formally only topics for scholars like Paracelsus, were simplified and made more accessible. It is sometimes astonishing to see the course that scholarly ideas have taken from the early modern period to the present. This can be illustrated by tracing the publishing history of just one love charm. In his Artzney Kunst und Wunderbuch (Book of Art and Wonder), published in Leipzig in 1592, the priest 
Michael Bapst gave a report about a way of counteracting the conjuring of love. One had to walk a certain distance in one's shoes until the feet began to sweat. Wine or beer must then be poured into the right-hand shoe and emptied in one gulp. These instructions were subsequently reported in Wolfgang Hildebrand's Magia Naturalis: Das ist Kunst und Wunderbuch, which first appeared in Darmstadt and Leipzig in 1610. Next, in 1699, Eberhard Gockel recommended taking these steps against magical love and love potions in his Tractatus Polyhistoricus Magico-Medicus Curiosus. Die bekannten Hundert acht und dreysig Geheimnisse (The famous one hundred and thirty eight secrets). An edition dating from 1737 contains the same receipt. In 1790 the charm appeared again in Eberhardt Heinrich Fischer's Albertus Magnus der Andere (Albertus Magnus the Other). The charm can also be found in the 'Pfuhler Hausbuch', a handwritten spell book from near Ulm, which was put together during the early nineteenth century. Around the mid-nineteenth century it appeared in print again in Albertus Magnus bewährte und approbierte sympathetische und natürliche Geheimnisse für Menschen und Vieh (Albertus Magnus's tried and tested sympathetic and natural secrets for men and animals). In the 1930 s it was reproduced in Franz Rupfer's cheap tract, Sympathiemittel für Menschen und Tiere (Sympathetic remedies for men and animals) (Kempten, 1931), and in an edition of the Sixth and Seventh Books of Moses sold by the Dresden book distributors Gutenberg. More recently it found its way into another edition of the Book of Moses printed in 1979 and again in Berlin in 1996.

The instructions given in such books for achieving wealth, happiness and good health were not only handed down for their antiquarian interest. They were also put to everyday use, and they influenced the daily practices of their owners and users. We are familiar with this fact from a number of sources, and I have come to know it through my own investigations, but one of the best piece of evidence comes from the influential German folklorist Adolf Spamer, who analysed the letters sent to a grimoire publisher from Dresden during the 1930s. A postman from Magdeburg, for example, wrote about wanting to hunt for hidden treasure and for this reason was looking to obtain Dr Faust's current address, as he had already sent three letters to Wittenberg, a town connected with Faust according to the chapbook legend, which had been sent back stamped 'return to sender'. A farmer from Mecklenburg asked:

Send me a book with which, one is sure to discover gold ... I also have the 6th and 7th Books of Moses, but that is too difficult to learn and involves too many costs, I also have a poor memory and I cannot understand it either. Please be so kind as to send me the sort of book which one only has to read and a ghost comes and inquires after one's wishes and then shows one where to get the gold.

In 1933 a woman enquired about obtaining a goblin, preferably in a jar a she said, and closed her letter by declaring, 'I am all in favour of magic.' 49 
The Germanist Peter-André Alt believes that some of the main currents and leading characteristics of the Enlightenment were the education of the people, the delatinisation of established education, the expansion of the media market, the improvement of technical possibilities for the printing trade and the more efficient structuring of its sales department', the suppression of an authoritative church and secularisation. ${ }^{50}$ It was these mechanisms and principles of the Enlightenment that opened the path of magic to everyone. The folklorist Christoph Daxelmueller has further explained how from the time of the Enlightenment scholars also turned away from the pansophic-magic explanation of the world and, in doing so, their knowledge was passed on into the hands of those who were not so much concerned with philosophical knowledge of the world as with their own immediate applicable benefits. ${ }^{51}$ In the shadows cast by the light of the Enlightenment, the transmission of magical knowledge was easier than ever before, and its impact far-reaching, with ripples reaching us today in the form of the current popularity of esoteric literature. Not surprisingly, the spread of occult literature was viewed as unwelcome competition by religious authorities. When, in the 1920s, a Munich occult bookshop had advertisements sent out to every household in the locality, the Klerusblatt, the mouthpiece of the diocese and its associated Economic Association Limited, responded by drawing up a plan 'to counteract true evil with an effective dam'. ${ }^{52}$

As Sabine Doering-Manteuffel has already indicated, the influence of the German magic media market was also felt in the New World. Germans who emigrated to America, particularly to Pennsylvania, brought with them their books of spells, especially the Sixth and Seventh Books of Moses. During the 1850 s and 1860 s the German version published by Scheible was reprinted to cater for the immigrant community, and in 1880 the work was translated into English and published in Chicago, New York and Philadelphia. ${ }^{53}$ As well as the Sixth and Seventh Books of Moses, German emigrants to Pennsylvania brought over Albertus Magnus' Egyptian Secrets or The Romanus Book. The German influence was also prominent in Johann Georg Hohmann's The Long Lost Friend, a popular collection of medical and magical receipts printed during the mid-nineteenth century. ${ }^{54}$ Much of the Long Lost Friend was, in fact, taken from The Romanus Book with some additions from other sources. ${ }^{55}$ The ownership of spell books found expression in fabulous and sinister stories and legends, whose motifs we also know from Germany, and which are documented in the collection of the Deutsche Sagen Archiv (German Legend Archive) in Freiburg. Faith healers and witch doctors, whose services were hardly distinguishable from those of their European colleagues, also established themselves amongst the Pennsylvanian Germans, and no doubt found the American magic books most useful.

The contents of the spell books developed in two distinctive ways once they began to be published in America. First, the old recipes were adapted 
to suit the conditions of the new environment. New animals, plants and minerals were inserted. In the charm books of Germany, for example, the oil of earthworms was said to be a tried and tested remedy for rheumatism, but in America it was replaced by rattlesnake oil. ${ }^{56} \mathrm{~A}$ single element of the unit construction system was exchanged without the recipe actually being altered. Secondly, in America magic knowledge from Germany fused with the traditions of the other ethnic groups. Thus the Sixth and Seventh Books of Moses was incorporated into the Afro-American population's Hoodoo beliefs. During the mid-1920s, Newbell Niles Puckett reported that the sale of the book was " "enormous" and its use widespread among Negroes in the American South'. ${ }^{7}$ Copies of the Moses grimoire also reached the islands of the West Indies. In Jamaica, a reggae group even recorded a song entitled 'Six and Seven Books of Moses'. Hohmann's The Long-Lost Friend also spread amongst various populations in America, 'to the Negro, the Cajun in Louisiana, the hill man in the Ozarks and other groups'. ${ }^{58}$ For both processes, the composition of charm books consisting of movable and exchangeable elements was a vital prerequisite for success in new environments, across centuries and social levels. It was not necessary to replace the entire textual context but only the individual elements when taking the needs of the new environment into account.

Further detailed investigation of the transatlantic relationship between charm books should prove an exciting and worthwhile task, particularly if it recorded and evaluated the magic books, manuscripts and pamphlets that still survive in America and compared them to those existent in Germany during the eighteenth and nineteenth centuries. Further work also needs to be conducted on the influence the dissemination of spell books in America may have had, in turn, on Europe. Is there any proof of reimportation? One thinks of the American influence on the New Age and esoteric movements. How much does the modern renaissance of occult and magic practices owe to the grimoires that originated in Enlightenment Germany?

\section{Notes}

1 Sabine Doering-Manteuffel, Josef Mancal and Wolfgang Wüst (eds), Pressewesen der Aufklärung (Berlin, 2001).

2 Holger Böning and Reinhart Siegert, Volksaufklärung: biobibliographisches Handbuch zur Popularisierung aufklärerischen Denkens im deutschen Sprachraum von den Anfängen bis 1850, 5 vols (Stuttgart, 1990-2001).

3 See, for example, Werner Faulstich, Medien zwischen Herrschaft und Revolte: die Medienkultur der frühen Neuzeit (1400-1700) (Göttingen, 1998); Werner Faulstich, Die bürgerliche Mediengesellschaft (1700-1830) (Göttingen, 2002); Robert Darnton, Mesmerism and the End of the Enlightenment in France (Cambridge, Mass., 1968); Adrian Johns, The Nature of the Book: Print and Knowledge in the Making (Chicago, 1997).

4. See, for example, Judith Devlin, The Superstitious Mind: French Peasants and the Supernatural in the Nineteenth Century (New Haven and London, 1987), ch. 7; Owen 
Davies, Witchcraft, Magic and Culture 1736-1951 (Manchester, 1999), ch. 3; Faith Wigzell, Reading Russian Fortunes: Print Culture, Gender and Divination in Russia from 1765 (Cambridge, 1998).

5 See, for example, the influential work of Johann Heinrich Jung-Stilling, Theorie der Geister-Kunde, in einer Natur-Vernunft- und Bibelmäsigen Beantwortung der Frage: Was von den Ahnungen, Gesichten und Geistererscheinungen geglaubt und nicht geglaubt werden mïße (Nuremberg, 1808).

6 This is illustrated by the development of spiritism in Germany. See Diethard Sawicki, Leben mit den Toten. Geisterglaube und die Entstehung des Spiritismus in Deutschland 1770-1900 (Paderborn, 2002).

7 For examples see Andreas Kopp, Das Pfuhler Hausbuch. Transkription und Kommentierung einer volksmedizinischen Handschrift aus dem Ulmer Raum (Ulm, 1998).

8 For example, Neu-erstandener Sonderlich-curioser Sibyllen-Geist. Bestehend in einer vermuthlichen Prognosticir- oder Vorsagung Auß dem Stern-Lauff Uber die vier Jahrs-Zeiten (Vienna, 1710).

9 Nikolaus Basse, Wunder seltzame Geschicht/von einer armen Frawen und fuenff kleiner Kindern oder Weißlinen/ welche fuer ir essen schlaffend auff einem gesaeyten Korn acker gefunden (Frankfurt am Main. Event dated 25 January 1572). Peter Hug, Wunder seltzame Geschicht/von einer armen Wittfrawen und fuenff kleiner Kinder/welche für ir essen schlaffend auff einem gesaeyten Kornacker gefunden (Strasburg. Event dated 30 January 1571).

10 Bruno Weber (ed.), Wunderzeichen und Winkeldrucker 1543-1586. Einblattdrucke aus der Sammlung Wickiana in der Zentralbibliothek Zürich (Zürich, 1972).

11 See, for example, Bernward Deneke and Kaspar Goltwurm, 'Ein lutherischer Kompilator zwischen Überlieferung und Glaube', in Wolfgang Brückner (ed.), Volkserzählung und Reformation. Ein Handbuch zur Tradierung und Funktion von Erzählsstoffen und Erzählliteratur im Protestantismus (Berlin, 1974), pp. 125-77; Robert Scribner, For the Sake of Simple Folk: Popular Propaganda for the German Reformation (Cambridge, 1981); Paul Russell, Lay Theology in the Reformation: Popular Pamphleteers in Southwest Germany, 1521-1525 (Cambridge, 1986).

12 Walter L. Strauss, The German Single-Leaf Woodcut 1550-1600, 3 vols (New York, 1975); Wolfgang Harms, Deutsche illustrierte Flugblätter des 16. und 17. Jahrhunderts (Tübingen, 1980).

13 Thiebold Berger, Warhaffte eigentliche Abbildung des wunderbaren schoenen Weitzenstocks (Strasburg, 1563). Later examples can be found in Erasmus Francisci, Der höllische Proteus, oder Tausendkiunstige Versteller, vermittels Erzehlung der vielfältigen Bild-Verwechslung erscheinender Gespenster (Nuremberg, 1695); Eberhard David Hauber, Bibliothekca Sive Acta et Scripta Magica, 3 vols (Lemgo, 1738-45).

14. Georg Kress, Eine Wahrhafftige und gantz trawrige newe Zeitung. So sich begeben und zugetragen im Böhmerland den vier und zweintzigisten Junij dises 1614 (Augsburg, 1614); Matthäus Pfeilschmidt, Eeine warhafttige und gantz trawrige newe Zeitung: So sich begeben und zugetragen im Böhmerland den vier und zweinzigisten Juni dises 1614 Jars in der Statt zu Plan genant (Hof, 1614).

15 Francisci, Der höllische Proteus. See also Johann Beaumont, Historisch-Physiologisch-und Theologischer Tractat von Geistern, Erscheinungen, Hexereyen und andern Zauber-Händern (Halle, 1721), which was a translation of John Beaumont, An Historical, Physiological and Theological Treatise of Spirits, Apparitions, Witchcrafts, and Other Magical Practices (London, 1705); Karl von Eckhartshausen, Sammlung der merkwuerdigsten Visionen, Erscheinungen, Geister- und Gespenstergeschichten (Munich, 1792).

16 Francisci, Der höllische Proteus, p. 226.

17 Rainer Alzheimer, 'Job Fincel und die Zeichen der Endzeit', in Wolfgang Brückner 
(ed.), Volkserzählung und Reformation. Ein Handbuch zur Tradierung und Funktion von Erzählstoffen und Erzählliteratur im Protestantismus (Berlin, 1974).

18 Augsburger Intelligenz-Zettel, no. 24, 1748; Augsburger Intelligenz-Zettel, no. 33, 1748.

19 Martin Welke, 'Zeitung und Öffentlichkeit im 18. Jahrhundert. Betrachtungen und Funktionen der periodischen deutschen Tagespublizistik', Presse und Geschichte. Beiträge zur historischen Kommunikationsforschung (Munich, 1977), pp. 71-99; Holger Bönisch, 'Bibliographie der deutschsprachigen Presse von den Anfängen bis 1815', Internationales Archiv für Sozialgeschichte der deutschen Literatur (Tübingen, 1992), pp. 110-37.

20 Jochen Brüning and Friedrich Niewöhner (ed.), Augsburg in der Frühen Neuzeit (Berlin, 1995); Helmut Gier and Johannes Janota (ed.), Augsburger Buchdruck und Verlagswesen - von den Anfängen bis zur Gegenwart (Wiesbaden, 1997).

21 See, for example, Philosophische Untersuchung von Gewalt und Wirckung des Teuffels in natürlichen Körpers (Frankfurt, 1704).

22 Dresdner Gelehrte Anzeigen aus den meisten Theilen der Gelehrsamkeit, der Künste und der Wissenschaften (Dresden, 1792-93).

23 Tobias Conrad Hoppe, Einige Nachricht von den sogenannten Eichen-, Weiden-, und Dorn-Rosen, welche in dem vorigen Jahr in der Lausitz ... sind gefunden worden (Leipzig, 1748); Johann Friedrich Schreiber, Sendschreiben an den Wohledlen und Wohlfürnehmen Herrn Tobias Conrad Hoppen (Gera, 1748); Hoppe, Antwort-Schreiben auf diejenigen Zweifel, welche der Wohlehrwürdige ... Johann Friedrich Schreiber zweyen Sendschreiben von den so genannten Weiden-Rosen ... entgegen gesetzt (Gera, 1748).

24 For example, Ob ein Hausvater mög mit guten gewissen unchristlich und Bäpstlich-Eehalten gedulden (Nuremberg, 1532); Christoph Meurer, Kurtz und nutzlich hauss-regiment darinnen grundlichen vermeldet und angezeiget wird wie ein hausvater sich und sein gesind vor der schrecklichen seuche der pestilentz huten sol (Leipzig, 1607); Johann Joachim Bechers, Kluger Haus-Vater, verständige Haus-Mutter, vollkommener Land-Medicus wie auch wohlerfahrner Ross- und Viehe-Artzt: nebenst e. deutl. u. gewissen Handgriff, $d$. Haushaltungs-Kunst innerhalb Stunden zu erlernen (Leipzig, 1747).

25 In 1686 they produced one of the most sumptuous illustrated editions of Luther's Bible ever produced. It was prepared for the Duke of Saxony, with richly gold-tooled recovers, spines and turn-ins and a binding in red morocco (goatskin).

26 For example, Alt und newer astrologischer Kriegs-Calender (Nuremberg, 1646); Astrologica practica (Nuremberg, 1669); Des Grossen Italiänischen Wahrsagers ... allgemeiner Welt- und Staats-Calender auf das Jahr 1714 (Nuremberg, 1713); Prognosticon generale oder Allgemeiner Astrologischer Discurs (Nuremberg, 1713).

27 A typical edition is Das ärgerliche Leben und schreckliche Ende deß vielberüchtigten Erzt-Schwartzkünstlers D. Johannis Fausti von Georg Rudolph Widmann. Jetzo, aus neue übersehen ... durch Joh. Nicolaum Pfitzerum (Nuremberg, 1681).

28 Das ärgerliche Leben und schreckliche Ende des vielberüchtigten Erzt-Schwartzkünstlers D. Johannis Fausti erstl. vor vielen Jahren, fleissig beschrieben von Georg Rudolph Widmann (Nuremberg, 1717); Johannes G. Scheffer, Anhang oder kurtzer Bericht von der Lappländer Zauber-Kunst (Nuremberg, 1717); Conrad W. Platz, Kurtzer, nothwendiger und wohl-gegründter Bericht von dem zauberischen Beschwören und Segensprechen (Nuremberg, 1717).

29 Der astrologischen Sybillen sinnreichen Weissagungen: welche in diesem verbesserten Stadtund Land-Calendar ... an das Tags-Licht gegeben werden (Nuremberg, 1727).

30 Berlinische Monatschrift 1 (1783) 376.

31 Andreas Riem, Über Aufklärung. Ob sie dem Staate - der Religion - oder überhaupt gefährlich sey, und sey könne? (Berlin, 1788), vol. 4; Etwas über Aufklärung und aufgeklärte Erziehung (1786). 
32 Johannes Hausmann, 'Über und wider den Aberglauben im deutschen Volke', Lehr und Mehr für's deutsche Volk 40 (1911) 1-16.

33 See, for example, Wayland Hand, Anna Casetta and Sondra B. Thiedermann (eds), Popular Beliefs and Superstitions: A Compendium of American Folklore (Boston, 1981), vol. 2.

34 See, however, the work of Linda Dégh, in particular American Folklore and the Mass Media (Bloomington, 1994).

35 Yvonne J. Millspaw, 'Witchcraft Belief in a Pennsylvania German Family', Pennsylvania Folklife 27, 4 (1978) 14-31.

36 See the legal and philosophical debates about witchcraft and magic in eighteenthcentury Germany, as discussed in Wolfgang Behringer, Witchcraft Persecutions in Bavaria: Popular Magic, Religious Zealotry and Reason of State in Early Modern Europe (Cambridge, 1997).

37 Hans Böhm, 'Strafverfahren gegen Schatzsucher in Dillingen und Lauingen. Zum Lauinger Christopherusgebet', Jahrbuch des Historischen Vereins Dillingen 89 (1977) 195-209.

38 Sabine Doering-Manteuffel, 'Medien, Märkte und Magie. Ein Augsburger Volkskundeprojekt zur kritischen Reflexion der Aufklärung', Bayerisches Jahrbuch für Volkskunde (2000) 1-14.

39 Hans Sebald, 'The 6th and 7th Books of Moses: The Historical and Sociological Vagaries of a Grimoire', Ethnologia Europea 18 (1988) 53-8; Karl-Peter Wanderer, Gedruckter Aberglaube: Studien zur volkstïmlichen Beschwörungsliteratur (Frankfurt, 1976).

40 Frank Möbus, 'Kein Meister über die Geister: Doctor Fausti "Höllenzwänge”, in Frank Möbus, Friederike Schmidt-Möbus and Gerd Unverfehrt (eds), Faust. Annäherung an einen Mythos (Göttingen, 1995), p. 47.

41 Hans Tümmler (ed.), Goethe's Briefwechsel mit Christian Gottlob Voigt (Weimar, 1962), vol. 4, p. 297.

42 Ferdinand Dieffenbach, 'Der letzte Adept', Die Gartenlaube 17 (1873) 279-82; Karl Esselborn, Darmstädter Originale (Darmstadt, 1919).

43 All the magical manuscripts mentioned in this section can today be found in the Handschriftenabteilung of the Hessische Landes- und Hochschulbibliothek, Darmstadt.

44 Das sechste und siebente Buch Mosis, das ist: Mosis magische Geisterkunst, das Geheimniß aller Geheimnisse. Wort- und bildgetreu nach einer alten Handschrift mit 23 Tafeln (Stuttgart, 1849). See Wanderer, Gedruckter Aberglaube, pp. 20-1.

45 For publication details see Wanderer, Gedrukter Aberglaube, pp. 77-85.

46 The original is housed in the British Library; see also the facsimile reprint, Hans Henning (ed.), D. Faust's original Geister Commando der Höllen und aller ander Geister Zwang (Leipzig, 1979).

47 See Johann Scheible, Das Kloster. Weltlich und geistlich Meist aus der ältern deutschen Volks-, Wunder-, Curiositäten-, und vorzugsweise komischen Literatur (Stuttgart, 1847), vol. 5, pp. 1159-1200.

48 Johann Christoph Adelung, Geschichte der menschlichen Narrheit oder Lebensbeschreibungen berühmter Schwarzkïnstler, Goldmacher, Teufelsbanner, Zeichen- und Liniendeuter, Schwärmer, Wahrsager, und anderer philosophischer Unholden. Sechster Theil (Leipzig, 1788), p. 345.

49 Adolf Spamer, 'Zauberbuch und Zauberspruch', Deutsches Jahrbuch für Volkskunde 1 (1955) 109-26.

50 Peter-André Alt, Aufklärung (Stuttgart, 1996).

51 Christoph Daxelmüller, Zauberpraktiken. Eine Ideengeschichte der Magie (Zürich, 1993). 52 Cyrillus Wehrmeister, 'Benedichte! Ein Beitrag zum Aberglauben der Gegenwart', 
Klerusblatt. Organ der Diözesan-Priestervereine Bayerns und ihres Wirtschaftlichen Verbandes G. m. b. H. 47 (1925) 397.

53 Kevin J. Hayes, Folklore and Book Culture (Knoxville, 1997), p. 17.

54 See, for example, Johann Georg Hohmann, The Long Lost Friend, or, Faithful \&̊ Christian Instructions Containing Wonderous and Well-Tried Arts \& Remedies (Harrisburg, 1850).

55 Don Yoder, 'Folk medicine', in Don Yoder (ed.), Discovering American Folklife: Studies in Ethnic, Religious and Regional Culture (Ann Arbor, 1990), p. 99.

56 Karl Knortz, Streifzüge auf dem Gebiete amerikanischer Volkskunde (Leipzig, 1902), p. 56.

57 Hayes, Folklore, p. 18.

58 Yoder, 'Folk Medicine', 99. 